\title{
Review: Dampak Negatif Indospicine dalam Indigofera sp. pada Ternak
}

\author{
Yanuartono $^{1}$, Hary Purnamaningsih ${ }^{1}$, Soedarmanto Indarjulianto ${ }^{1^{*}}$, \\ Alfarisa Nururrozi ${ }^{1}$, Slamet Raharjo ${ }^{1}$ \\ Departemen Ilmu Penyakit Dalam, Fakultas Kedokteran Hewan Universitas Gadjah Mada \\ J1. Fauna No.2, Karangmalang, Depok, Sleman. 55281 Yogyakarta, Indonesia \\ Tel : +62-274-560862, Fax +62-274-560861
}

Email korespondensi: indarjulianto@ugm.ac.id

(Diterima 15-10-2019; disetujui 28-04-2020)

\begin{abstract}
ABSTRAK
Pakan merupakan aspek penting dari peternakan dan peningkatan produksi daging dapat dicapai melalui nutrisi dan manajemen yang tepat. Indigofera sp adalah salah satu spesies leguminosa hijauan yang potensial untuk ruminansia dan merupakan sumber penting protein, mineral, vitamin, serat serta memiliki palatabilitas tinggi. Genus Indigofera terdiri atas sekitar 700 spesies yang berbeda, banyak di antaranya adalah tanaman penting yang secara agronomis digunakan sebagai pakan ternak dan suplemen pakan. Namun, beberapa spesies Indigofera mengandung faktor antinutrisi dikenal sebagai indospicine yang merupakan asam amino nonprotein toksik (2,7- diamino-7-iminoheptanoic acid) dan diketahui bersifat hepatotoksik pada ruminansia. Ternak yang mengonsumsi Indigofera dilaporkan mengalami efek hepatotoksik dengan adanya lesi pada hati, efek teratogenik dan kematian embrio. Oleh karena itu, indospicine harus dipertimbangkan sebagai kemungkinan penyebab rendahnya penampilan ternak, khususnya penurunan berat badan dan gangguan reproduksi pada ruminansia yang diberi pakan indigofera sp dalam jumlah yang berlebihan. Di Indonesia spesies Indigofera zollingeriana merupakan pilihan paling tepat untuk dibudidayakan dan dikembangkan sebagai pakan ternak rumiansia karena memiliki kandungan indospicine yang rendah untuk menghilangkan kejadian keracunan indospicine.
\end{abstract}

Kata kunci: faktor antinutrisi, hepatotoksik, indigofera, indospicine

\begin{abstract}
The feed is an important aspect of animal production, an increase in meat production can be achieved through proper nutrition and good management. The Indigofera $\mathrm{sp}$ is one of the potential forage legume species which are important sources of protein, minerals, vitamins, fiber, and has high palatability that provide essential nutrients for ruminants. The Indigofera genus contains approximately 700 different species, many of which are agronomically important plants that are used as grazing forages and feed supplements. Some Indigofera species, however, contain antinutritional factors (ANF) known as indospicine, a toxic nonprotein amino acid (2,7- diamino-7-iminoheptanoic acid) and is thought to be hepatotoxic in ruminants. Cattle and sheep consuming Indigofera have been reported to experience both hepatotoxic effects with associated liver lesions, and also teratogenic and embryo-lethal effects. Therefore, indospicine should be considered as a possible cause of animal poor performance, particularly reduced weight gain and reproductive disorders in ruminants that are fed with excessive amounts of indigofera sp. in Indonesia Indigofera zollingeriana species are the most appropriate choice to be cultivated and developed as ruminat livestock feed because they have a low indospicine content to eliminate the incidence of indospicine poisoning.
\end{abstract}

Keywords: antinutritional factor, hepatotoxic, Indigofera $s p$, indospicine 


\section{PENDAHULUAN}

Tanaman leguminosa telah dikenal memiliki potensi sebagai sumber pakan untuk ternak rumianansia yang berkualitas tinggi, terutama saat musim kering dimana ketersediaan hijauan rumput segar menurun tajam. Tanaman leguminosa memiliki nilai lebih sebagai pakan ternak, karena selain memiliki kualitas nutrisi yang lebih tinggi juga mampu menyediakan bahan pakan yang stabil dalam jangka yang lebih panjang dibandingkan dengan jenis hijauan rumput. Salah satu jenis tanaman leguminosa yang mulai banyak dimanfaatkan adalah Indigofera $s p$. karena mudah dibudidayakan dan tahan terhadap kekeringan, sehingga dapat menjadi alternatif sumber pakan pada musim kemarau. Indigofera sp. merupakan tanaman family Fabaceae dengan genus Indigofera $s p$. yang memiliki sekitar 700 spesies dan tersebar di Benua Afrika, Asia, Australia serta Amerika Utara (Schrire et al., 2009). Indigofera sp dibawa ke Indonesia pada sekitar tahun 1900 oleh bangsa Eropa dan saat ini telah berkembang secara luas (Schrire, 1995). Indigofera sp kaya akan protein, mineral serta kandungan serat kasar tinggi sehingga mampu meningkatkan efisiensi pakan dan meningkatkan pertumbuhan serta produktivitas ternak ruminansia (Ngo van Man et al. (1995). Ali et al. (2014) dan Tarigan et al. (2018) menambahkan pernyataan bahwa Indigofera $s p$ dapat dimanfaatkan sebagai pakan ternak karena kaya akan nitrogen, fosfor dan kalsium. Menurut Yurmiaty (2006) dan Edwards et al. (2012) Indigofera $s p$ sangat baik dimanfaatkan sebagai hijauan pakan ternak karena mengandung protein kasar 27,9\%, serat kasar 15,25\%, tingkat kecernaan $77 \%$, kalsium $0,22 \%$, dan fosfor $0,18 \%$. Selain merupakan sumber pakan ternak yang yang kaya akan nutrisi, Indigofera $s p$ juga toleran terhadap musim kering, genangan air dan tahan terhadap salinitas yang cukup tinggi (Coughenour et al., 1990; Mapfumo et al., 2005; Haryadi, 2013; Nadir et al., 2018). Jumlah dan variasi jenis Indiofera yang ada di dunia sangat tinggi yang tersebar diseluruh wilayah tropik dan subtropik (Prabakaran et al., 2011). Meskipun demikian, sebagai hijauan pakan ternak Indigofera memiliki kelemahan karena mengandung beberapa antinutrisi seperti indospicine, alkaloids, flavonoids, saponins, dan tanin yang jika terkonsumsi secara berlebihan akan memiliki dampak negatif pada ternak.

Jenis Indigofera yang mulai banyak dimanfaatkan sebagai pakan ternak di Indonesia adalah Indigofera zollingeriana. Telah banyak penelitian dan tulisan yang membahas manfaat Indigofera sebagai pakan ternak yang memiliki nilai gizi yang tinggi, namun demikian masih sedikit penelitian maupun bahasan mengenai kandungan bahan antinutrisi Indigofera $s p$. utamanya indospicine yang dapat berdampak negatif terhadap ternak yang mengkonsumsinya. Tulisan ini mencoba membahas dampak negatif indospicine yang terkandung dalam Indigofera $s p$ yang digunakan sebagai pakan ternak sehingga para peternak dapat lebih berhati hati dalam memberikannya.

\section{KANDUNGAN NUTRISI INDIGOFERA SP}

Indigofera $s p$. merupakan salah satu tanaman hijauan pakan ternak dari kelompok leguminosa yang memiliki potensi besar untuk digunakan sebagai bahan pakan basal pengganti rumput ataupun pengganti konsentrat sumber protein untuk ruminansia. Indigofera $s p$. memiliki produktivitas yang tinggi dengan kandungan nutrien yang cukup tinggi dan lengkap (Sherman, 1982). Menurut Tarigan \& Ginting (2011) Indigofera $s p$. dalam ransum berbasis rumput Brachiaria ruziziensis dapat meningkatkan konsumsi dan kecernaan serta efisiensi penggunaan ransum yang selanjutnya meningkatkan pertambahan berat badan harian pada ternak ruminansia.

Indigofera zollingeriana adalah spesies yang relatif baru dikembangkan sebagai pakan ternak di Indonesia karena memiliki kandungan protein yang tinggi setara dengan rumput alfalfa, yaitu 28-32\% (Koten et al., 2014), serat kasar 38,30-51,05\% (Catchpoole \& Henzell, 1971), ADF 28,6-42,29\% (Abdullah, 2010), kalsium 1,16-1,78\%, fosfor 0,26-0,31\%, kalium 1,3-1,4\% magnesium 0,450,51\% (McDonald et al., 1995; Tukan et al., 1998). Hasil penelitian kandungan nutrisi pada Indigofera $s p$ cukup bervariasi seperti disajikan pada Tabel 1 .

Tabel 1 menunjukan variasi nilai gizi dari berbagai spesies Indigofera. Variasi nilai gizi dari berbagai spesies Indigofera yang terlihat pada tabel 1 dapat disebabkan oleh berbagai macam faktor. Nilai nutrisi hijauan pakan tergantung pada spesies/varitas, lingkungan (tanah, iklim, penggembalaan), bagian tanaman dan umur tanaman (Nelson \& Moser,1994; Pearson \& Ison, 1997; Kumalasari et al., 2017). Herdiawan \& Krisnan (2014) menambahkan bahwa kandungan nutrisi tanaman sangat dipengaruhi oleh tingkat kesuburan media tanam dan beberapa faktor daya dukung lingkungan biotik. 
Tabel 1. Kandungan nutrisi berbagai macam Indigofera $s p$

\begin{tabular}{|c|c|c|c|c|c|}
\hline \multirow{2}{*}{ Jenis } & \multicolumn{4}{|c|}{ Kandungan (\%) } & \multirow{2}{*}{ Pustaka } \\
\hline & $\begin{array}{c}\text { Bahan kering } \\
(\mathrm{BK})\end{array}$ & $\begin{array}{c}\text { Protein } \\
\text { kasar }(\mathrm{PK})\end{array}$ & $\begin{array}{l}\text { Serat kasar } \\
\quad(\mathrm{SK})\end{array}$ & $\begin{array}{c}\text { Lemak } \\
\text { kasar (LK) }\end{array}$ & \\
\hline Indigofera sp (daun) & - & 27,88 & $22-46$ & - & Hassen et al., 2007 \\
\hline $\begin{array}{l}\text { Indigofera gerardiana } \\
\text { (daun) }\end{array}$ & - & 3,7 & 17,80 & 2,37 & Nisar et al., 2009 \\
\hline Indigofera sp.(daun) & 21,97 & 24,17 & 17,83 & 6,15 & $\begin{array}{l}\text { Simanihuruk \& Sirait, } \\
2009\end{array}$ \\
\hline I. astragalina (daun) & - & 8,23 & 2,67 & 5,00 & Gafar et al., 2011 \\
\hline Indigofera sp (daun) & 21,97 & 24,17 & 17,83 & 6,15 & Sirait et al., 2012 \\
\hline I.tinctoria (bunga) & - & 2,63 & 19,65 & 1,00 & Chandra et al., 2014 \\
\hline I. zollingeriana (daun) & - & 28,98 & 8,49 & 3,3 & Palupi et al., 2014 \\
\hline Indigofera sp. (daun) & 29,9 & 23,1 & - & - & Ali et al., 2014 \\
\hline Indigofera sp. (daun) & - & 27,9 & 15,25 & 6,93 & $\begin{array}{l}\text { Nurhayu \&Pasambe, } \\
2016\end{array}$ \\
\hline Indigofera sp (daun) & 26,99 & 23,01 & 21,05 & - & $\begin{array}{l}\text { Setiyaningrum et al., } \\
2017\end{array}$ \\
\hline I. zollingeriana (daun) & 25.61 & 31,77 & 16,75 & - & Jusoh \& Hafifah, 2018 \\
\hline
\end{tabular}

Keterangan: - (data tidak ada)

\section{MANFAAT INDIGOFERA SP SEBAGAI PAKAN TERNAK}

Indigofera $s p$ merupakan leguminosa pohon yang sangat potensial sebagai bahan pakan ternak karena memiliki karakteristik pertumbuhan dan adaptasi yang baik, toleransi tinggi terhadap kekeringan, banjir dan salinitas serta memiliki palatabilitas tinggi sebagai pakan ruminansia (Sherman, 1982). Indigofera termasuk dalam genus besar dengan sekitar 700 spesies serta tersebar merata di benua Afrika tropis (Hassen et al., 2008), Asia (Hutapea et al., 2018), Australia (Wilson \& Rowe, 2010), dan Amerika Utara serta Selatan (Campos et al., 2018). Indigofera sp. tersebar luas mulai dari kondisi kering hingga daerah lembab pada ketinggian 1500 sampai 3000 meter (Shinwari et al., 2006). Indigofera sp. yang sampai saat ini lazim digunakan sebagai pakan ternak adalah I.astragalina (Gafar et al., 2011), I. cryptantha (Hassen et al., 2008), I. cornuligera dan I. arrecta (Wilson \& Rowe, 2010), I. tinctoria (Yaman et al., 2012), I. australis ( O'Keeffe et al., 2014) dan I. suffruticosa (Campos et al., 2018). Sedangkan di Indonesia, jenis yang paling banyak dibudidayakan adalah Indigofera zollingeriana. Menurut Sirait et al. (2009), Indigofera zollingeriana memiliki kemampuan produksi yang tinggi pada umur delapan bulan dengan rata-rata produksi biomasa segar per pohon sekitar 2,595 $\mathrm{kg} /$ panen dan dengan total produksi segar sekitar 52 ton/ha/tahun. Berbagai macam jenis Indigofera $s p$ tersebut telah banyak dimanfaatkan sebagai sumber pakan ternak, baik ruminansia maupun non ruminansia. Selain ternak ruminansia, Indigofera $s p$. dapat dimanfaatkan sebagai bahan pakan ayam petelur dan puyuh (Yaman et al., 2012), ayam potong (Santi, 2017), ikan (Pangentasari et al., 2018), kelinci (Al Iqwal et al., 2018). Sebaliknya, Indigofera sp. tidak dianjurkan digunakan sebagai pakan kuda karena banyak kasus laporan kejadian kuda yang menderita keracunan setelah mengkonsumsi Indigofera $s p$. (Carroll \& Swain, 1983; Lima et al., 2012).

Banyak hasil penelitian menunjukkan bahwa Indigofera $s p$. sangat potensial dan bermanfaat sebagai pakan ternak (Rosadi et al., 2018; Wijaya et al., 2018). Hasil penelitian Barokah et al. (2017) menunjukkan bahwa Penambahan $40 \%$ Indigofera zollingeriana pada pelepah kelapa sawit dapat meningkatkan kandungan PK dan BETN dan menurunkan kadar SK silase pelepah kelapa sawit. Adanya penambahan biomassa Indigofera yang memiliki kandungan SK yang rendah ddiduga menjadi penyebab penurunan kadar SK silase pelepah kelapa sawit. Simanihuruk \& Sirait (2009) meneliti manfaat daun Indigofera sp. sebagai pakan basal pengganti rumput lapangan terhadap pertumbuhan kambing Boerka. Parameter pada penelitian teresbut adalah rataan konsumsi bahan kering pakan, pertambahan bobot hidup dan efisiensi penggunaan pakan. Hasil penelitiannya menunjukkan bahwa konsumsi bahan kering, bahan organik, pertambahan bobot hidup dan efisiensi penggunaan pakan tidak dipengaruhi oleh substitusi rumput oleh pemberian Indigofera sp. meskipun demikian, Indigofera sp. potensial untuk 
digunakan sebagai pakan basal pengganti rumput karena Konsumsi $\mathrm{N}$ meningkat secara nyata seiring dengan peningkatan komposisi Indigofera $s p$. sebagai pengganti rumput lapangan. Hasil penelitian Nurhayu \& Pasambe (2016) menunjukan bahwa sapi potong jantan dengan pakan basal rumput gajah yang diberi tambahan 40-60\% Indigofera $s p$ dapat meningkatkan bobot badan $0,51 \mathrm{~kg} / \mathrm{ekor} / \mathrm{hari}$ dan menurunkan konversi pakan dari 14,3 menjadi 11,1. Lebih lanjut menurut Ginting et al. (2010) Indigofera sp dapat digunakan sebagai pakan hijauan tunggal pada kambing meskipun tidak mampu meningkatkan performans sehingga tetap disarankan untuk menggunakan konsentrat protein tinggi untuk meningkatkannya. Indigofera $s p$ juga berperan dalam proses perkembangan organ reproduksi jantan, proses spermatogenesis, serta proses produksi, penyimpanan dan sekresi hormon testosteron ternak ruminansia karena banyak mengandung $\mathrm{Ca}$, Mg, Mn dan Zn (Hassen et al. (2007). Penambahan I. zollingeriana pada pakan kambing perah dapat meningkatkan konversi pakan, kecernaan bahan kering, efisiensi pakan dan produksi rata rata susu per hari (Abdullah et al., 2012). Hasil-hasil penelitian menunjukan bahwa Indigofera $s p$. sangat potensial untuk dimanfaatkan sebagai pakan ternak ruminansia besar maupun kecil dalam meningkatkan penampilan secara keseluruhan. Potensi tersebut berdasarkan kandungan protein kasar dan mineral yang tinggi sehingga Indigofera sp. dapat dijadikan sumber protein pengganti konsentrat dan juga sebagai sumber mineral.

\section{FAKTOR ANTI NUTRISI INDIGOFERA SP}

Indigofera $s p$ saat ini telah banyak dimanfaatkan sebagai leguminosa sumber pakan ternak, baik ruminansia maupun non ruminansia. Namun demikian ada faktor faktor pembatas yang harus dicermati guna menghindari kejadian keracunan yang tidak diharapkan. Beberapa spesies Indigofera $s p$ telah dilaporkan dapat meracuni ternak yang mengonsumsinya seperti I. spicata, I hirsuta dan I. lespedezioides (Aylward et al., 1987;
Brown \& Pitman, 1991; Brown et al., 1991; Lima et al., 2012). Indigofera sp. mengandung faktor anti nutrisi/anti nutrition factor (ANF) seperti alkaloids, flavonoids, saponins,dan tannins (Herdiawan et al., 2014). Penelitian oleh Sharma \&Agarwal (2015) dengan menggunakan metode ekstraksi hidrometanol pada tanaman I. tinctoria menunjukkan bahwa tanaman tersebut mengandung ANF seperti flavonoid $(104,16 \mathrm{mg} / \mathrm{g}$ berat kering), saponin $(87,5 \mathrm{mg} / \mathrm{g}$ berat kering), tanin $(230 \mathrm{mg} / \mathrm{g}$ berat kering), dan fenol $(210.62$ $\mathrm{mg} / \mathrm{g}$ ). Sampai saat ini, studi kasus maupun hasil penelitian yang menyangkut Indigofera $s p$ tidak pernah menunjukkan adanya keracunan ANF yang terkandung dalam Indigofera $s p$ kecuali indospicine yang telah terbukti banyak mengakibatkan keracunan pada berbagai macam ternak. Sampai saat ini informasi mengenai palatabilitas dan toksisitas dari sekitar 700 spesies Indigofera masih sedikit. Hal tersebut menjadi tantangan bagi para ahli nutrisi ternak untuk mengkaji dan meneliti potensi dari spesies Indogofera yang aman digunakan sebagai pakan ternak baik ruminansia maupun non ruminansia. Tabel 2 menunjukkan kandungan indospicine dari berbagai spesies Indigofera.

Tabel 2 menunjukkan variasi kandungan indospicine pada berbagai spesies Indigofera. Meskipun telah banyak dikembangkan sebagai pakan ternak di Indonesia, namun demikian penelitian tentang kandungan indospicine pada Indigofera zollingeriana tidak pernah dilakukan. Hal tersebut kemungkinan karena kandungan indospicine pada Indigofera zollingeriana cukup rendah sehingga dianggap aman untuk diberikan pada ternak. Menurut Miller \& Smith (1973), pada biji Indigofera zollingeriana tidak terdeteksi adanya indospicine, namun penelitian tidak dilakukan pada daun, dengan demikian seharusnya masih diperlukan penelitian terhadap kandungan indospicine pada daun yang dimanfaatkan untuk pakan ternak.

Tabel 2. Kandungan indospicine dari berbagai spesies Indigofera

\begin{tabular}{lll}
\hline \multicolumn{1}{c}{ Indigofera sp. } & \multicolumn{1}{c}{ Kandungan Indospicine } & \multicolumn{1}{c}{ Pustaka } \\
\hline I. arrecta & $126,1 \mathrm{mg} / \mathrm{kg} \mathrm{DM}$ & Hassen et al., 2008 \\
I.hendecaphylla & $500,00 \mathrm{mg} / \mathrm{kg} \mathrm{DM}$ & Ossedryver et al., 2013 \\
I. spicata & $500-2000 \mathrm{mg} / \mathrm{kg} \mathrm{DM}$ & Aylward et al., 1987 \\
I. lespedezioides & $1178 \mu \mathrm{g} / \mathrm{g}$. & Lima et al., 2012 \\
I. praticola & Tidak terdekteksi & Gardner \& Riet-Correa,2011 \\
I. tinctoria & Tidak terdeteksi & Gardner \& Riet-Correa,2011 \\
\hline
\end{tabular}




\section{DAMPAK INDOSPICINE PADA TERNAK}

Antinutrisi yang dianggap paling berbahaya bagi ternak dari Indigofera $s p$ adalah indospicine (asam L-6-amidino-2-aminoheksanoat) analog dengan arginin (Tan et al., 2016). Indospicine pertama kali diisolasi oleh Hegarty \& Pound pada tahun 1968 dari I. spicata dan toksisitasnya dikaitkan dengan penghambatan aktivitas arginase, penghambatan penggabungan arginin ke dalam protein dan penghambatan aktivitas nitric oxide synthase (Madsen et al., 1970, Pass et al., 1996). Lebih lanjut dinyatakan bahwa indospicine ditemukan hanya pada spesies tanaman Indigofera dan terbatas pada sejumlah kecil spesies dalam genus ini (Sherman et al., 1998; Hassen et al., 2008). Menurut Schrire et al. (2009), 6 spesies Indigofera yang memiliki kandungan tinggi indospicine adalah I. hendecaphylla, I. linnaei, I. lespedezioides, I. spicata, I. vicioides dan I. volkensii. Strictland et al. (1987) menyatakan bahwa sekitar 50\% spesies Indigofera dilaporkan dapat menyebabkan keracunan dan penurunan palatabilitas pada hewan. Namun demikian, laporan penelitian Strictland et al. (1987) tersebut menggunakan tikus sebagai hewan coba sehingga sulit untuk disimpulkan pada ternak ruminansia dan lebih tepat pada hewan monogastrik. Dengan demikian hasil penelitian yang saling bertentangan tersebut masih membutuhkan kajian kajian dan penelitian untuk membuktikan seberapa jumlah spesies Indigofera yang dapat menimbulkan keracunan pada ternak ruminansia.

Laporan terkait dengan keracunan indospicine sebenarnya telah ada sejak lama dimana ternak sapi yang mengkonsumsi Indigofera $s p$. menunjukkan adanya lesi pada hati dan juga efek teratogenik serta kematian embrio (Nordfeldt et al., 1952). Indospicine adalah asam amino nonproteinogenik yang ditemukan terdapat dalam tanaman Indigofera $s p$ dan dikenal dapat menjadi residu bersifat toksik dalam jaringan tubuh hewan yang memiliki pola makan merumput (Hegarty et al., 1988; Fletcher et al., 2016). Laporan selanjutnya oleh Hegarty \& Pound (1968) adalah I. spicata terbukti bersifat hepatotoksik pada domba, sapi dan kelinci serta dapat menyebabkan aborsi pada hewan bunting. Fletcher et al. (2016) dalam penelitian mengungkapkan bahwa pedet yang digembalakan dan mengkonsumsi I. spicata di padang penggembalaan dalam jangka panjang dapat menderita hepatotoksikosis dan gangguan reproduksi yang diakibatkan oleh indospicine yang terkandung dalam tanaman tersebut dan dapat menjadi residu dalam jaringan tubuh secara persisten. Hasil penelitian oleh (Nordfeldt et al., 1952) menunjukkan bahwa sapi dan domba dengan pemberian pakan yang mengandung $I$. spicata segar sejumlah dari 30\% hingga 100\% selama 15 hari secara bertahap menunjukkan penurunan nafsu makan dan berat badan. Gejala lain yang muncul pada beberapa hewan adalah gangguan sistem syaraf pusat dengan tanda tanda hewan menjadi malas bergerak, mengantuk, berjalan berputar-putar dengan posisi kepala rendah, namun demikian gejala tersebut akan menghilang dalam satu atau dua hari. Lebih lanjut, jika hewan diberi pakan mengandung I. spicata dalam waktu lebih lama akan menunjukkan pertumbuhan yang terhambat dan ditemukan lesi pada hati.

Sampai saat ini telah banyak hasil penelitian yang menunjukkan bahwa manifestasi klinis akibat keracunan indospicine tergantung pada spesies hewan (Fletcher et al., 2015). Meskipun demikian ruminansia tampaknya lebih resisten terhadap indospicine karena kemampuan mikroflora dalam rumen mendegradasi. Tan et al. (2016) dalam penelitiannya juga menyatakan bahwa indospicine dapat dimetabolisme oleh sistem mikroba dalam rumen sehingga menjadi tidak bersifat toksik. Sebaliknya dengan non ruminansia yang tidak memiliki enzim yang mampu mendegradasi sehingga lebih rentan terhadap indospicine (Fowler, 1983; Hegarty, 1986). Dampak keracunan indospicine sampai saat ini lebih banyak teramati pada hewan non ruminansia. Kasus kasus keracunan indospicine teramati pada domba, marmot (Nordfeldt et al., 1952), kelinci ( Hutton et al., 1958), tikus (Christie et al., 1969), mencit (Hegarty \& Pound,1970) kuda (Lima et al., 2012), anjing (Fitzgerald et al., 2011). Kasus keracunan indospicine sekunder pada anjing yang mengkonsumsi daging kuda dan unta yang terkontaminasi indospicine telah dilaporkan oleh Hegarty et al. (1988) dan Fitzgerald et al. (2011). Meskipun demikian, pada kenyataannya, indospicine dapat mengakibatkan keracunan pada organ hati semua spesies hewan dan telah terbukti melalui laporan penelitian maupun studi lapangan adanya kasus keracunan hati yang bersifat akut maupun sub kronis pada berbagai macam spesies hewan. Hassen (2008) dalam penelitiannya memberikan solusi untuk mengatasi masalah keracunan indospicine pada ruminansia seperti (a) seleksi dan pengembangan spesies Indigofera rendah indospicine, (b) identifikasi umur dan bagian tanaman yang paling optimal untuk pakan, (c) pembuatan silase Indigofera, (d) menentukan 
volume Indigofera yang tepat dalam campuran bahan pakan, (e) dan mengidentifikasi mikroba rumen yang memiliki kemampuan mendetoksifikasi indospicine.

Menurut Herdiawan dan Krisnan (2014), di Indonesia Indigofera $s p$ belum banyak dimanfaatkan untuk hijauan pakan meskipun tanaman tersebut sudah ada sejak lama. Hal ini dikarenakan kurangnya informasi, publikasi, kajian serta penelitian baik di laboratorium maupun di lapangan. Hal tersebut menjadi alasan kemungkinan belum adanya laporan kejadian keracunan indospicine pada ternak di Indonesia. Kemungkinan yang lain adalah dari gejala klinis yang muncul tidaklah menciri sehingga para praktisi dilapangan mengalami kesulitan dalam mendiagnosa kasus keracunan indospicine. Kejadian keracunan indospicine kemungkinan memang belum pernah muncul karena hasil kajian kajian penelitian di Indonesia banyak menggunakan spesies Indigofera zollingeriana yang memiliki kandungan indospicine yang rendah (Suharlina, 2012). Hal tersebut menjadikan Indigofera zollingeriana merupakan pilihan spesies paling sesuai yang dapat dikembangkan dengan risiko munculnya keracunan indospicine menjadi sangat rendah. Namun demikian, dengan semakin meningkatnya penggunaan tanaman Indigofera $s p$ sebagai alternatif sumber hijauan pakan ternak, sudah selayaknya para peneliti, ahli nutrisi hewan dan praktisi mulai mengamati kasus kasus dilapangan dimana ternak banyak mengkonsumsi Indigofera $s p$.

\section{KESIMPULAN}

Salah satu jenis tanaman leguminosa pohon yang mulai banyak dieksplorasi adalah Indigofera $s p$. karena mudah dibudidayakan dan tahan terhadap kekeringan, sehingga dapat menjadi alternatif sumber pakan pada musim kemarau. Dampak negatif indospicine dalam Indigofera $s p$ pada ternak pada ternak dapat berupa keracunan hati yang bersifat akut maupun sub kronis., namun demikian karena saat ini di Indonesia yang paling banyak dibudi dayakan adalah spesies Indigofera zollingeriana yang memiliki kandungan indospicine rendah maka kejadian keracunan indospicine sampai saat ini tampaknya tidak pernah terjadi.

\section{DAFTAR PUSTAKA}

Abdullah, L. 2010. Herbage production and quality of shrub Indigofera treated by different concentration of foliar fertilizer. Med Pet
33:169-175. doi.org/10.5398/medpet.2010. 33.3.169.

Abdullah, L., D. Apriastuti, \& T.A.P. Apdini. 2012. Use of Indigofera zollingeriana as a forage protein source in dairy goat rations. Proc. Asia dairy Goat Conference Malaysia: 71-72.

Al Iqwal, Y., R. Rastina, A. Harris , T.R. Ferasyi, Al Azhar, \& M. Akmal. 2018. The Effect of Indigofera sp. leaf on the protein level of rabbit meat (Orictolagus sp). Jurnal Medika Veterinaria 12: 97-102. DOI:https://doi.org/ 10.21157/j.med.vet.v1 1i1.4065.

Ali, A., L. Abdullah, P.D.M.H. Karti, M.A. Chozin, \& D.A. Astuti. 2014. Production and nutritive value of Indigofera zollingeriana and Leucaena leucocephala in Peatland. Animal Production 16:156-164.

Aylward, J.H., R.D. Court, K.P. Haydock, R.W. Strickland, \& M.P. Hegarty, 1987. Indigofera species with agronomic potential in the tropics. Rat toxicity studies. Australian Journal of Agricultural Research 38:177-186. DOI:10.1071/ar9870177.

Barokah, Y., A. Ali, \& E. Erwan. 2017. Nutrisi silase pelepah kelapa sawit yang ditambah biomassa indigofera (Indigofera zollingeriana). Jurnal Ilmu-Ilmu Peternakan. 20(2):59-68. DOI: 10.22437/jiiip.v20i2.4772.

Brown, W.F. \& W.D. Pitman, 1991. Concentration and degradation of nitrogen and fiber fractions in selected tropical grasses and legumes. Tropical Grasslands 25:305-312.

Brown, W.F., Z.Q. Lai, \& W.D. Pitman, 1991. In vitro fibre digestion: associative effects in tropical grass-legume mixtures. Tropical Grasslands 25: 297-304.

Campos, J.K.L., T.F.S. Araújo, T.G.S. Brito, A.P. S. da Silva, R.X. da Cunha, M.B. Martins, N.H. da Silva, B.S. dos Santos, C.A. da Silva, \& V.L.M. Lima. 2018. Indigofera suffruticosa mill. (Anil): plant profile, phytochemistry, and pharmacology review. Advances in Pharmacological Sciences. 2018:1-6. DOI:10.1155/2018/8168526.

Carroll, A.G. \& B.J. Swain. 1983. Birdsville disease in the Central highlands area of Queensland. Aust Vet J 60:316-317. DOI: 10.1111/j.1751-0813.1983.tb02827.x. 
Catchpoole, V.R. \& E.F. Henzell. 1971. Silage and silage making from tropical herbage species, Herbage Abstracts 41:213-221.

Chandra, S., S. Saklani, A.P. Mishra, \& G. Rana. 2014. Nutritional, anti-nutritional profile and phytochemical screening of flowers of Indigofera tinctoria from Garhwal Himalaya. International Journal of Herbal Medicine 1:23-27.

Christie, G.S., N.P. Madsen, \& M.P. Hegarty. 1969. Acute biochemical changes in rat liver induced by the naturally-occurring amino acid indospicine. Biochem Pharmacol 18: 693-700. DOI:10.1016/0006-2952(69) 90039-2.

Coughenour, M.B., D.L. Coppock, M.M. Rowland, \& J.E. Ellis. 1990. Dwarf shrub ecology in Kenya's arid zone: Indigofera spinosa as a key forage resource. Journal of Arid Environment. 18: 301-312. DOI: 10.1016/S0140-1963(18)30840-1.

Edwards, A., V. Mlambo, C. Lallo, \& G.W. Garcia. 2012. Yield, chemical composition and in vitro ruminal fermentation of the leaves of Leucaena leucocephala, Gliricidia sepium and Trichanthera gigantea as Influenced by harvesting frequency. J. Anim Sci Adv 2:321-331.

Fitzgerald, L.M., M.T. Fletcher, A.E.H. Paul, C.S. Mansfield, \& A.J. O'hara. 2011. Hepatotoxicosis in dogs consuming a diet of camel meat contaminated with indospicine. Australian Veterinary Journal 89:95-100. DOI:10.1111/j.1751-0813.2010.00684.x.

Fletcher, M.T., R.A.M. Al Jassim, \& A.J. CawdellSmith. 2015. The occurrence and toxicity of indospicine to grazing animals. Agriculture 5:427-440. DOI:10.3390/agriculture5030427.

Fletcher, M.T., K.G. Reichmann, S.M. Ossedryver, R.A. McKenzie, P.D. Carter, \& B.J. Blaney. 2016. Accumulation and depletion of indospicine in calves (Bos taurus) fed creeping indigo (Indigofera spicata). Anim. Prod Sci 58:568-576. DOI:10.1071/ AN16394.

Fowler, M.E. 1983. Plant poisoning in free-living wild animals: A review. J. Wildl. Dis. 19: 34-43. DOI:10.7589/0090-3558-19.1.34.

Gafar, M.K., A.U. Itodo, F.A. Atiku, A.M. Hassan, \& I.J. Peni. 2011. Proximate and mineral composition of the leaves of hairy indigo
(Indigofera astragalina). Pak J Nutr 10: 168-175. DOI: 10.3923/pjn.2011.168.175.

Gardner, D.R., \& F.Riet-Correa. 2011. Analysis of the toxic amino acid indospicine by liquid chromatography-tandem mass spectrometry. IJPR 1:20-27.

Ginting, S.P., R. Krisnan, J. Sirait, \& A.Chaniago. 2010. Pemanfaatan Indigofera sp sebagai hijauan tunggal pada kambing yang diberi konsentrat dengan kandungan karbohidrat atau protein tinggi. JITV 15(4):261-268.

Haryadi, 2013. Pengukuran luas daun dengan metode simpson. Anterior. 12(2):1-5. DOI:10.33084/anterior.v12i2.299

Hassen, A., N.F.G. Rethman, Z. Apostolides, \& W.A. Van Niekerk. 2008. Forage production and potential nutritive value of 24 shrubby Indigofera accessions under field conditions in South Africa. Tropical Grasslands. 42:96-103.

Hassen, A., N.F.G. Rethman, W.A. Van Niekerk, \& T.J. Tjelele 2007. Influence of season/year and species on chemical composition and in vitro digestibility of five indigofera accession. Journal Animal Feed Science and Technology 136:312-322. DOI:10.1016/j.anifeedsci. 2006.09.010

Hegarty, M.P. \& A.W. Pound. 1968. Indospicine, a new hepatotoxic amino-acid from Indigofera spicata. Nature 217:354355. DOI:10.1038/217354a0.

Hegarty, M.P., \& A.W. Pound. 1970. Indospicine, a hepatotoxic amino acid from Indigofera spicata: isolation, structure, and biological studies. Aust J Biol Sci 23:831-842. DOI:10.1071/bi9700831.

Hegarty, M.P. 1986. Toxic amino acids in foods of animals and man. Proc Nutr Soc Australia 11:73-81.

Hegarty, M.P., W.R. Kelly, D. McEwan, O.J. Williams, \& R. Cameron. 1988. Hepatotoxicity to dogs of horse meat contaminated with indospicine. Aust Vet J 65:337-340. DOI:10.1111/j.1751-0813.1988. tb14259.x.

Herdiawan, I. \& R. Krisnan. 2014. Produktivitas dan Pemanfaatan Tanaman Leguminosa Pohon Indigofera zollingeriana pada Lahan Kering. Wartazoa 24:75-82 DOI:10.14334/ wartazoa.v24i2.105175. 
Herdiawan, I., L. Abdullah, \& D. Sapandi. 2014. Nutritional status of Indigofera zollingeriana forage at different level draught stress and cutting interval. JITV 19 : 91-103. DOI:10.14334/jitv.v19i2.1037.

Hutapea, P.S., L. Abdullah, P.D.M.H. Kartia, \& I. Anas. 2018. Improvement of Indigofera zollingeriana production and methionine content through inoculation of nitrogenfixing bacteria. Tropical Animal Science Journal 41:37-45. DOI:10.5398/tasj.2018. 41.1.37.

Hutton, E.M., G.M., Windrum, \& C.C. Kratzing. 1958. Studies on the toxicity of Indigofera endecaphylla: I. Toxicity for rabbits. J. Nutr. 64: 321-337. DOI:10.1093/jn/64.3.321.

Jusoh, S. \& C.S.N. Hafifah. 2018. Nutritive value, palatability, and selectivity of 10 different legume herbages by rabbits. Mal. J. Anim. Sci. 21: 69-75.

Koten, B.B., R. Wea, R.D. Soetrisno, N. Ngadiyono, \& B. Soewignyo. 2014. Konsumsi nutrien ternak kambing yang mendapatkan hijauan hasil tumpang sari arbila (Phaseolus lunatus) dengan sorghum sebagai tanaman sela pada jarak tanam arbila dan jumlah baris sorgum yang berbeda. Journal of Animal Science 1:38-45. DOI:10.24198/jit.v14i1.5146

Kumalasari, N.R., G.P. Wicaksono, \& L. Abdullah. 2017. Plant growth pattern, forage yield, and quality of Indigofera zollingeriana influenced by row spacing. Media Peternakan. 40:14-19 DOI:10.5398/medpet. 2017.40.1.14.

Lima, E.F., F. Riet-Correa, D.R. Gardner, S.S. Barros, R.M.T. Medeiros, M.P. Soares, \& G. Riet-Corre. 2012. Poisoning by Indigofera lespedezioides in horses. Toxicon. 60: 324-328. DOI:10.1016/ j.toxicon.2012.04.341.

Madsen, N.P., G.S. Christie, \& M.P. Hegarty. 1970. Effect of indospicine on incorporation of L-arginine-14C into protein and transfer ribonucleic acid by cell-free systems from rat liver. Biochem Pharmacol 19:853-857. DOI:10.1016/0006-2952(70)90247-9.

Mapfumo, P., F. Mtanbagengwe, K.E. Giller, \& S. Mpepereki. 2005. Tapping indigenous harbacous legumes for soil fertility management by resources - poor farmer in
Zimbabwe. Agriculture, Economic System and Environment 109:221-223. DOI: 10.1016/j.agee.2005.03.015.

McDonald, P., R.A. Edward, F.D. Greenhalti, \& C.A. Morgan, 1995. Animal nutrition. Prentices Hall, London.

Miller, R.W., \& C.R. Smith Jr. 1973. Seeds of Indigofera species. Their content of amino acids that may be deleterious. J Agric Food Chem 21: 909-912.

Nadir, M., M.J. Anugrah, \& P.I. Khaerani. 2018. Salt salinity tolerance on nursery of Indigofera zollingeriana. IOP Conf. Series: Earth and Environmental Science 156 (2018):012027. DOI:10.1088/1755-1315/ $156 / 1 / 012027$

Nelson, C.J., \& L.E. Moser. 1994. Plant Factors Affecting Forage Quality. In: Forage Quality, Evaluation, and Utilization. G.C. Fahey, JR., M. Collins, D.R. Mertens, and L.E. Moser (Eds.) American Society of Agronomy, Crop Science Society of America, Soil Science Society of America. 115-154.

Ngo van Man, Nguyen van Hao, \& Vuong minh Tri. 1995. Biomass production of some leguminous shrubs and trees in Vietnam. Livestock Res Rural Dev 7:1-5.

Nisar, M., S.A. Tariq, \& Ihsanullah. 2009. Nutritional levels of Indigofera Gerardiana wall and crataegus songrica K. Koch. Pak J Bot 41:1359-1361.

Nordfeldt, S., L.A. Henke, K. Morita, H. Matsumoto, M. Takahash, O.R. Younge E.H. Willers, \& R.F. Cross. 1952. Feeding Tests with Indigofera endecaphylla Jacq. (creeping indigo) and some observations on its poisonous effects on domestic animals. Technical Bulletin No. 15; Hawaii Agriculture Experiment Station, University of Hawaii. Honolulu, HI, USA. pp. 5-23.

Nurhayu, A., \& D. Pasambe. 2016. Indigofera Sebagai Substitusi Hijauan pada Pakan Sapi Potong di Kabupaten Bulukumba Sulawesi Selatan. Seminar Nasional Peternakan 2, Fakultas Peternakan Universitas Hasanuddin Makassar, 25 Agustus 2016.

O'Keeffe, P.A., D.J. Orchard, B.A. Orchard, J.W. Piltz, \& E.H. Clayton. 2014. Native Australian shrub legume species may provide an alternative feed source for 
livestock Animal Production Science. 55: 1090-1096. DOI:10.1071/AN14505.

Ossedryver, S.M., G.I. Baldwin, B.M, Stone, R.A. McKenzie, A.W. van Eps, S. Murray, \& M.T. 2013. Fletcher Indigofera spicata (creeping indigo) poisoning of three ponies. Aust Vet J 91:143-149.

Palupi, R., L. Abdullah, D.A. Astuti, \& Sumiati. 2014. Potential and utilization of Indigofera sp. shoot leaf meal as soybean meal substitution in laying hen diets. JITV 19: 210-219. DOI:10.14334/jitv.v1913.1084.

Pangentasari, D., M. Setiawati, N.B.P. Utomo, \& M.T.D. Sunarno. 2018. Komposisi dan nilai kecernaan nutrien tepung daun tarum (Indigofera zollingeriana) yang difermentasi dengan cairan rumen domba pada benih ikan jelawat Leptobarbus hoevenii (Bleeker, 1851). Indonesian Journal of Ichthyology 18(2):165-173. DOI:10.32491/jii.v18i2.314.

Pass, M.A., A. Hossein, S. Pollitt, \& M.P. Hegarty. 1996. Effects of the naturally occurring arginine analogues indospicine and canavanine on nitric oxide mediated functions in aortic endothelium and peritoneal macrophages. Natural Toxins. 4:135-140. DOI:10.1002/19960403NT6.

Pearson, C.J., \& R.L. Ison. 1997. Agronomy of grassland systems. 2nd ed. Cambridge (UK): Cambridge University Press.

Prabakaran, M., N. Chandrakala, \& A. Panneerselvam. 2011. Antimicrobial activity of Indigofera glandulosa (wild). Asian Journal of Plant Science and Research $1: 18-25$

Rosadi, K., L. Abdullah, N.R. Kumalasari, \& M.A.Yaman. 2018. Evaluasi Peforma Benih Indigofera zollingeriana dari tanaman berbeda umur. Bulletin Makanan Ternak 105(1):1-10.

Santi, M.A. 2017. Penggunaan tepung pucuk Indigofera zollingeriana sebagai pengganti bungkil kedelai dalam ransum dan pengaruhnya terhadap kesehatan ayam broiler. Jurnal Peternakan 01:17-22.

Schrire, B.D. 1995. Evolution of the tribe indigofereae (leguminosainosae papilionoideae). In: Crisp MD, Doyle JJ, editors. Advances in leguminosaes systematics parts 7: phylogeny. London (UK): Royal Botanic Gardens Kew. p. 161-244.
Schrire, B.D., M. Lavin, N.P. Barker, \& F. Forest. 2009. Phylogeny of the tribe indigofereae (leguminosae papilionoideae): geographically structured more in succulent-rich and temperate settings than in grass-rich environments. Am J Bot 96:816-852.

Setiyaningrum, E., I.N. Kaca, \& N.K.E. Suwitari. 2017. Pengaruh umur pemotongan terhadap produksi dan kualitas nutrisi tanaman indigofera (Indigofera $s p$ ). Gema Agro 23(1):59-62. DOI:10.22225/ga.23.1.660.5962.

Sharma, V., \& A. Agarwal. 2015. Physicochemical and Antioxidant Assays of Methanol and Hydromethanol Extract of Ariel Parts of Indigofera tinctoria Linn. Indian J Pharm Sci 77:729-734.

Shinwari, Z.K., T. Watanabe, M. Rehman, \& T. Youshikawa. 2006. A pictorial guide to Medicinal Plants of Pakistan. KUST. Kohat, Pakistan.

Simanihuruk, K. \& J. Sirait. 2009. Pemanfaatan leguminosa pohon Indigofera Sp. Sebagai pakan basal kambing boerka fase pertumbuhan. Prosiding Seminar Nasional Teknologi Peternakan dan Veteriner "Teknologi Peternakan dan Veteriner Mendukung Industrialisasi Sistem Pertanian untuk Meningkatkan Ketahanan Pangan dan Kesejahteraan Peternak" Bogor, 13-14 Agustus 2009. Hlm 449-455.

Sirait, J., K. Simanihuruk, \& R. Hutasoit 2009. The potency of Indigofera sp. as goat feed: production, nutritive value and palatability. In: Proceeding of International Seminar on Forage Based Feed Resources. Bandung, 37 Agustus 2009. Taipei (Taiwan): Food and Fertilizer Technology Centre (FFTC) ASPAC, Livestock Research Centre-COA, ROC and IRIAP. p. 4-7.

Sirait, J., K. Simanihuruk, \& R. Hutasoit. 2012. Potensi Indigofera sp. sebagai pakan kambing: produksi, nilai nutrisi dan palatabilitas. Pastura 1(2):56-60.

Sherman, P.J. 1982. Tropical Forage Legumes. Food and Agriculture Organization: Rome, FAO, FAO Plant Production and Protection Series No 2.

Sherman, P.J., D.G. Cameron, \& F. Riveros. 1988. Tropical Forage Legumes, 2nd ed.; Food 
and Agricultural Organisation of the United Nations. Rome, Italy.

Strictland, R.W., I.J. Lamborne, \& D. Ratckliff. 1987. A rat bioassay for screening tropical leguminous forages and seed for palatability and toxicity. Aust J Exp Agric 27:45-43. DOI:10.1071/EA9870045.

Suharlina. 2012. Manfaat Indigofera sp. dalam bidang pertanian dan industri. Pastura 2(1): 30-33.

Tan, E.T., C.M. Materne, R.G. Silcock, B.R., D’Arcy, R. Al Jassim, \& M.T. Fletcher. 2016. Seasonal and species variation of the hepatotoxin indospicine in Australian Indigofera legumes as measured by UPLCMS/MS. J Agric Food Chem 64:6613-6621. DOI:10.1021/acs.jafc.6b02437.

Tarigan, A., \& S.P. Ginting. 2011. Pengaruh taraf pemberian Indigofera sp. terhadap konsumsi dan kecernaan pakan serta pertambahan bobot hidup kambing yang diberi rumput Brachiaria ruziziensis. JITV 16:25-32.

Tarigan, A., S.P. Ginting, A. Ali, D.A. Astuti, \& L. Abdullah. 2018. Body weight gain, nutrients degradability and fermentation rumen characteristics of boerka goat supplemented green concentrate pellets (GCP) based on indigofera zollingeriana. Pak J Biol Sci 21:87-94. DOI:10.3923/pjbs.2018.87.94.
Tukan, S.K., H.R. Takruri, \& D.M. Al-Eisaw. 1998. The use of wild edible plants in the Jordanian diet. International Journal of Food Science and Nutrition 49:225-235. DOI:10.3109/09637489809086416

Wijaya, A.S., T. Dhalika, \& S. Nurachma. 2018. Pengaruh pemberian silase campuran Indigofera $s p$. dan rumput gajah pada berbagai rasio terhadap kecernaan serat kasar dan BETN pada domba garut Jantan. Jurnal Ilmu Ternak 18:47-52. DOI: 10.24198/jit.v18i1.16499.

Wilson, P.G., \& R. Rowe. 2010. New taxa and typifications in Indigofera (Fabaceae) for South Australia. J Adelaide Bot Gard 24:6773.

Yaman, M.A., M. Daud, Zulfan, Y., Jufri, \& T. F. Karmil. 2012. Evaluation of viability and nutritive value of Indigofera tinctoria as a potential animal feeding in Aceh Province, Indonesia The Proceedings of The 2nd Annual International Conference Syiah Kuala University 2012 \& The 8th IMT-GT Uninet Biosciences Conference Banda Aceh, 22-24 November 2012.

Yurmiaty, H. 2006. Hubungan Berat Potong Kambing Kacang Jantan dengan Kuantitas Kulit Mentah Segar. Journal of Animal Science. 6:121-125. DOI: 10.24198/jit.v6i2. 2279. 